\title{
YONTMATAŞ BULUNTU TOPLULUKLARI IŞIĞINDA ANKARA: Neyi Biliyoruz? Neyi Bilmiyoruz? Yeni Değerlendirmeler ve Sonuçlar
}

\author{
Metin KARTAL
}

\begin{abstract}
For no apparent reason, Central Anatolian Paleolithic Age studies have been neglected since the mid $20^{\text {th }}$ century. And it seems that our knowledge is very poor about knapped stone findings in this region. The goal of this study is hopefully to provoke a debate among the Paleolithic Age archaeologists. Some of previous researchers such as Kansu, Kökten, Ozansoy, Pfannenstiel etc. mainly focused on Ankara's knapped stone findings during the mid $20^{\text {th }}$ century. We must also acknowledge Campbell-Thompson, Bittel, İnan and Pittard who had worked in this region in the first half of the $20^{\text {th }}$ century prior to Kansu and his friends. What we mainly find in the papers of these researchers are impressive terms such as: "levalloiso-moustérien", "aurignacien" and "tardenoasian". But today, some questions that come to mind are "Are these the correct terms for Central Anatolia?", "What were the shortcomings of earlier research?" and "What answers can we propose today?"
\end{abstract}

First of all, we must consider not only the geographic position of Central Anatolia but also the possible cultural connections between the Balkans and the Levant and/or the Taurus-Zagros cultural zone. Some archaeologists whom we have consulted thought that Central Anatolia doesn't play a role in the distribution of bifacial tools. Yet since it is obviously possible to see that the necessary evidence has already been obtained from Central Anatolia, today this hypothesis seems absolutely speculative. On the other hand, beside the existence of the bifacial tools which belong typologically to the lower Paleolithic period, there are also many findings from the middle Paleolithic period that reflect the moustérien type of assemblages with or without the levallois knapping strategies. Up to now, we have no basis for saying the aurignacien tradition is present in Central Anatolia. But this tradition is currently identified in the Karain B cave's sequence in southwestern Anatolia in the new excavations. Although, it seems impossible to identify tardenoasian culture not only in Central Anatolia but also all around Anatolia on the basis of existing data. It is not surprising that we also have some findings of possible food production phases from Ankara. It is known that the Aşıkl1, Çatalhöyük and Pınarbaşı sites represent the first food production phases in Central Anatolia. Of course we can not give absolute data about this period from these few findings. We must consider these findings as initial clues from Ankara and its surroundings.

Consequently, in addition to the surface collections of knapped stone findings, Ankara and its surrounding territories need more in situ findspots to establish the cultural sequence and the dates of this cultural sequence's sub-phases during the pleistocene and the beginning of the holocene.

\section{GİRIȘ}

$\mathrm{Bu}$ çalışma, Ankara'nın özellikle il merkezi ve kısmen de yakın çevresinden eski araştırmalarla ele geçmiş olan yontmataş buluntuların yeniden değerlendirilmesi ama- cyyla gerçekleştirilmiştir. Elimizdeki buluntular az sayıda olmakla birlikte, Ankara'nın yontmataş endüstrilerine ilişkin bilgilere daha sistemli bir veri tabanı oluşturabilecek niteliktedir. 


\section{I.1. Tarihçe ve Sorun}

Ankara'nın ilk Paleolitik Çağ buluntuları 1910 yilında R.Campbell-Thompson tarafindan Uzağıl'da ve 1931'de Kurt Bittel tarafindan Ankara'daki havagazı fabrikasının batısında bulunmuştur. Uzağıl'dan ele geçenlerin moustérien tip aletler ve havagazı fabrikası yakınından ele geçenlerin ise mavimsi çakmaktaşlarından yontulmuş Paleolitik aletler olduğu bildirilmektedir ${ }^{1}$. Bununla birlikte Kansu, Ankara ve çevresindeki sistemli Prehistorik araştırmaların Dil ve Tarih-Coğrafya Fakültesi'nin kurulmasından sonra (1936 yılından itibaren) başladığını ve bölgedeki Paleolitik eserlerin ilk izlerine Muine Atasayan tarafindan Gavurkale'de rastlanıldığını bildirmektedir ${ }^{2}$. Bunun ardından yapılan diğer araştırmalar; Etiyokuşu, Ergazi Köyü, Ludumlu Köyü, Güdül, Gazi Enstitüsü civarı, Keçiören, Elmadağ etekleri, İlhan Köyü, Kızılcahamam-Çeştepe, Beypazar1-Karaköy, Macunçay, Üreğil, İmrehor, Gölbaşı, Mogan Gölü kıyıları, VirancıkGerder-Bursal köyleri arası, Dikmen sırtları, Hüseyingazi Tepesi etekleri, Taşpınar-Yalıncak arasındaki kaya sığınakları ve Orman Çiftliği-Sincanköy arasındaki alanların yontmataş endüstri buluntu topluluklarını gün 1şığına çıkarmıştır ${ }^{3}$. Tüm bu araştırma ve buluntuları, Profesör Kökten yazmış olduğu şu kelimelerle açıklamaktadır: "Ankara Başşehir olduktan ve Kurumlarla, Fakülteleri bağrına bastıktan sonra Anadolu'nun en çok araştırılan bir köşesi oldu"». $\mathrm{Bu}$ araştırmalardan sonra Kökten'in de yazmış olduğu gibi birçok buluntu yeri ile karşılaşılmış ve kendisinin 1945 yılında Ankara'da yapmış olduğu araştırmalar çok önemli belgeleri gün ışı̆̆ına çıkarmıştır. Ne var ki, 1950'lerden sonra Ankara ve

Kansu 1940, 1

2 Kansu-Ozansoy 1952, 381; Aynı zamanda bkz. İnan 1938, 301

3 Kansu-Ozansoy 1952, 381-383

4 Kökten 1947b, 434 çevresinde Paleolitik Çă̆ Arkeolojisi'ne ilişkin hiçbir çalışma yapılmamıştır. Dolayısıyla da 20. yüzyılın ikinci yarısından sonra Ankara ve yakın çevresi Paleolitik Çağ buluntularına rastlamak tesadüflerden öteye gidememiştir.

Prehistorya'nın Ülkemizdeki duayeni olan Profesör Kökten 1952 yılında yayınladığı bir yayınında ise şöyle yazmıştır: "Ankara çevresinin Paleolitik buluntu yerleri birer istasyon mudur? Değillerse nerelerden taşınmışlardır? En yüksek sekiler üzerinde toplanan ve alt pleistosen safhaya idhaline temayül gösterdiğini bildirdiğim aletlerle, Ankara çevresinin Paleolitik buluntuları arasında bir münasebet çıkacak mıdır? Bu soruların da cevaplarl, ancak yardımcı bilim kollariyle yapılacak sıkı is birliğinden sonra verilebilecektir" ". Gerçekten de Kökten Ankara buluntularının ne denli önemli olduğunu ve bunların izahlarının interdisipliner çalışmayla çözülebileceğini daha 1950'lerde yazıya dökmüştür. Kökten'in bu sorularının cevabı hala açığa kavuşmamıştır. Umarız Ankara çevresinin sistemli çalışmalarının başlamasıyla hem bizlerin hem de Kökten'in soruları detaylı bir şekilde araştırılır.

\section{I.2. Amaç Kapsam ve Yöntem}

Çalışmamızın başında belirtmiş olduğumuz söz konusu buluntuların yeniden değerlendirilmesinin nedenlerini kısaca şöyle açıklayabiliriz: $\mathrm{Bu}$ buluntuların bir çoğu; 1930'lu ve 50'li yılları arasında incelenmiş olup, bir kısmı yayınlanmış, bir kısmı da yayına hiç girmemiştir. Çalışmamıza başlarken öncelikle, incelenmiş ve yayına girmiş olan bu yontmataş endüstri öğelerinin, tipolojik olarak ne kadar doğru sinıflandırılıp sınıflandırılmadığı hakkındaki kuşkularımızın ne denli geçerli olup olmadığını açığa çıkarmak istedik. Bunun sonucunda ise, bir

5 Kökten 1952, 180 
kısmının yeniden sinıflandırılması gerektiği kanısına vardık. Diğer taraftan, hiç değerlendirilmemiş olan yontmataş elemanların da incelenmesiyle, Ankara'nın elimizdeki yontmataş buluntu topluluklarının ilk sonuçları ortaya çıkmış bulunmaktadır.

Prof.Kökten tarafindan Ankara Üniversitesi, Dil ve Tarih-Coğrafya Fakültesi, Prehistorya Kürsüsü'ne getirilmiş olan ve bugün için Arkeoloji Bölümü, Prehistorya Anabilim Dalı koleksiyonunda bulunan yontmataş malzeme ile birlikte; Ankara çevresinde yaptığımız arazi yürüyüşleri sırasında karşımıza çıkan yontmataş eserler (toplam 62 adet), bizim çalışma materyallerimizi oluşturmuştur. $\mathrm{Bu} 62$ adet yontmataş eserin; buluntu yerleri, bulunuş şekilleri ve nicelikleri aşağıda açıklanmıştır:

Macunçay yüzey buluntusu (1 adet), Hüseyingazi yüzey buluntuları (3 adet), Etiyokuşu kazı ve yüzey buluntuları (10 adet), Keçiören yüzey buluntuları (13 adet), İlhan Çay1 yüzey buluntusu (1 adet), Sindıran-Yanıktarla yüzey buluntuları (5 adet), İvedik Köyü yüzey buluntuları (3 adet), Ergazi yüzey buluntuları (2 adet), Ergazi-I yüzey buluntuları (3 adet), Ergazi-II yüzey buluntuları (3 adet), Etimesgut yüzey buluntuları (3 adet), Çayyolu-Sondurak çevresi yüzey buluntuları (8 adet) ve Eryaman-4.Etap yüzey buluntuları (7 adet).

Yukarıda sıralamış olduğumuz 13 ayrı buluntu yerinden ilk 11'i eski araştırmalar sonucunda ele geçmiş olan buluntulardır. Son 2 buluntu yeri ise, Ankara çevresinde yapılan yürüyüşler sırasında tesadüfen ele geçmiş olan buluntuları temsil etmektedir. Yürüyüşler sırasında tesadüfen ele geçen tüm buluntular Ankara Anadolu Medeniyetleri Müzesi'ne teslim edilmiştir.

Çalıșmamızı yaparken karşılaştığımız en büyük zorluk, eski çalışmalarla ele geçmiş olan yontmataş malzemelerin, veri eksikliği nedeniyle bulunduğu kesin noktaların tespit edilememesi olmuştur. Örneğin Ergazi buluntuları yukarıda da görüleceği üzere 3 ayrı buluntu alanı olarak karşımıza çıkmıştır. $\mathrm{Bu}$ alanların birbirlerine göre olan konumları ne şekildedir bilemiyoruz. Bu türden sorunları dikkate alarak, tüm tespitlerimizi sadece adı geçen alanlardan bulunan malzemeler olarak değerlendirmek, uygulanabilecek en doğru yöntem gibi görünmektedir. Dolay1sıyla, Ankara'nın yontmataş eserleri açısından kültürel ve teknolojik görünümü, elimizde olan bilgiler dahilinde bir parça da olsa gün 1şığına kavuşacaktır diye düşünüyoruz. Detaylı bilgilere ulaşabilmek için yeni ve sistemli araştırmaların ve belki de "in situ" bir alan bulunduğu taktirde kazıların gerçekleştirilmesi gerekmektedir.

Söz konusu buluntuları, buluntu alanlarına göre yeniden inceleyerek açıklamak ve aynı zamanda daha önce yapılmış olan eski araştırmalarla karşılaştırmak konuyu anlaşılır kilacaktır.

\section{ANKARA ÇEVRESİ BULUNTU YERLERI}

\section{II.1. Macunçay}

Bilindiği üzere Macunçay buluntuları 1940'lı yıllarda gün 1şı̆̆ına çıkarılmış, Kansu ve Ozansoy tarafından yayınlanmıştır ${ }^{6}$. Bu yontmataş eserlerin nerede oldukları hakkında hiçbir fikrimiz yoktur. Ancak, Prehistorya Anabilim Dalı koleksiyonları içinde karşımıza çıkan sadece 1 adet yontmataş buluntu, bu satırları yazmamıza neden olmuştur. Söz konusu buluntu, distal uçtan eğik budanmış bir dilgidir (Fig.6:8). $\mathrm{Bu}$ alet, dorsal yüzündeki negatif dilgi izlerine dayanarak tek yönlü bir çıkarım tekniği göstermektedir. Tüm yüzeyinde

6 Kansu-Ozansoy 1952, 387-390 
sürüklenmeden dolayı doğal cilalanma oluşmuştur. Dolayısıyla "in situ" özelliğini kaybetmiştir. $\mathrm{Bu}$ durumda bu aletin kaynağını bulunduğu yerden daha yüksek kotlarda aramak daha doğrudur. Aynı şeyleri belki de Macunçay mikrolitik buluntuları için de düşünmek gerekmektedir. Ancak, bu buluntuların gerçek buluntu yerlerinin bilinmemesi, yer tespitinde bir kaos oluşturmaktadır. Buluntunun dönemi için kesin bir şey söylemek olanaksız olmakla birlikte, dilgi teknolojisinin gelişkin bir evresine sahip olmas1 nedeniyle tipolojik olarak Pleistosen sonuna ve belki de holosen döneme tarihleyebilmek mümkündür.

\section{II.2. Hüseyingazi}

İlk olarak M.Pfannenstiel, Hüseyingazi Tepesi'nin yamaçlarında üç yerde yontmataş aletler ele geçirmiş, ancak bu buluntuları 1 tanesi dişında (levalloiso-moustérien) belirli bir döneme ve kültürel komplekse bağlamamıştır ${ }^{7}$. Kansu ve Ozansoy, Ankara'nın doğusunda Üreğil'in arkasında ve Hüseyingazi Dağ 1 eteklerinde levalloiso-moustérien tipte kazıyıcı ve uçlar bulduklarını bildirmektedirler $^{8}$. Çalışma yapabildiğimiz 3 adet buluntudan sadece 1 tanesi tipik bir alettir. Her üç buluntu da dilgi olup, bunlardan ikisi dorsal yüzünde tek yönlü, diğeri ise iki yönlü çıkarım tekniğini yansıtmaktadır. Alet olarak tanımladığımız bu yontmataş buluntu (Fig.6:5); bir orak elemanı olup, kesme kenarlarında kullanım çentikleri ve kesme yüzlerinde ise kullanımdan dolayı oluşan cilalanma izleri göstermektedir. Dilginin her iki ucu da eğik budanmış olup, sırt kısmı düzelti taşımaktadır. $\mathrm{Bu}$ dilgi muhtemelen bir kompozit orak aletin elemanıdır. Büyük bir ihtimalle bitki besin üretim aşamasına ait olmakla birlikte, stratigrafi göstermediğinden

7 Harmankaya-Tanındı 1996

8 Kansu-Ozansoy 1952, 384 dolayı mutlak dönemini bildiremiyoruz. $\mathrm{Bu}$ durumda Hüseyingazi için Paleolitik döneme bağlanabilecek bir buluntu, Kansu ve Ozansoy'un bildirdikleri dışında bilinmemektedir.

\section{II.3. Etiyokuşu}

1937 yılında, Ankara-Çubuk Baraj1 karayolu üzerinde, Çubuk Suyu kenarında Paleolitik döneme ait çakmaktaşı aletler bulunmuştur. Kansu, bu aletlerin Çubuk Suyu'nun pleistosen çakıllıklarından çıkarıldığını ve bunların alt Paleolitik dönem levalloiso-moustérien'e ait olduklarını bildirmektedir'. Yayında, çakmaktaşlarının çıkarıldığ 1 ince çakıl ve kumlu seviyenin, Etiyokuşu stratigrafisinde $\mathrm{V}$. seviye olduğu ve bu seviyenin günümüzdeki Çubuk Suyu seviyesinden yaklaşı 10 metre daha yukarıda olduğu belirtilmektedir. Yine ayrıca bu seviye höyük toprağından 3.10 metre aşağıda tespit edilmiştir ${ }^{10}$.

Yayından anlaşılacağı üzere, Etiyokuşu'nun Paleolitik dönem seviyelerinden; bir adet elbaltası (yeni adlandırmasıyla iki yüzeyli alet), çeşitli uçlar, taş kalemler, kazıyıcılar ve çekirdekler ele geçmiştir. Kansu, bu alandan ele geçmiş olan yontmataş buluntuların Kökten tarafindan incelendiğini belirtmektedir. Bu çalışmaya göre Etiyokuşu buluntu toplulukları için aşağıdaki kültürel saptamalar yapılmıştır.

- Elbaltas1: Levalloisien ve Acheuléen

- Uçlar: Levalloisien ve LevalloisoMoustérien

- Taş Kalemler: Levalloisien

- Kazıyıcilar: Levalloisien ve Acheuléen

- Çekirdekler: Levalloisien

10 Kansu 1940, 3 
Yayından anlaş1lacağ adet yontmataş buluntu üzerinde çalış1mıştır ${ }^{11}$. Prehistorya laboratuvarında bulunan toplam 10 adet Etiyokuşu yontmataş buluntu üzerinde yapmış olduğumuz çalışmalar, Kansu ve Kökten'in yaptığı çalışma sonuçlarına göre biraz daha farklı bir çerçeve çizmemize neden olmuştur. Üzerinde çalıştığımız yontmataş malzemenin sadece 3 tanesi Kansu'nun yayınında yer almaktadır. Diğerlerine ulaşılamamıştır.

Kansu'nun 1940 yıl1 yayınındaki EY 24 numaralı levalloisien ve acheuléen'e bağlanan elbaltas1 ${ }^{12}$ (Fig.2:2), bizim yaptığımız çalışmaya göre şüpheli bir biçimde Acheuléen'e ve belki de erken orta Paleolitik döneme bağlanabilecek kısmi iki yüzeyli alet kategorisinde gruplanabilir. Buluntunun taş1malığı, aslında iri bir yongadır. Yonganın yumrusu ve topuğu içyüz çıkarımlarıyla kaldırılmış ve inceltilmiștir. Aletin dorsal yüzü üzerinde, dip kısmında hammadenin doğal yüzü ve kabuk kısmından küçük bir kalıntı taşımaktadır. Hammaddesi sütlü kahverengi çakmaktaşıdır. Aletin her iki yüzü de flüviyal akıntı ve doğal nedenlerden ötürü oldukça aşınmış ve cilalanmıştır.

EY 2 numaralı ve yayında uç olarak değerlendirilmiş olan alet ${ }^{13}$ (Fig.4:8); bizim yaptığımız inceleme sonucunda, taşımalığı levallois yonga olan dişlemeli alet kategorisinde sınıflandırılmıştır. Bu aletin kanımızca uç olarak sınıflandırılması mümkün değildir. Yonganın dorsal yüzü üzerindeki negatif izler, iki kutuplu levallois yontma tekniği içermektedir. Yonganın bir kenarı bütünüyle, diğer kenarı kısmi dişlemeli düzeltiler göstermektedir. Tipolojik açıdan bu alet orta Paleolitik döneme bağlanabilir.

11 Kansu 1940, 41-56

12 Kansu 1940, 44

13 Kansu 1940, 48
Kansu'nun yayınında levallois uç olarak tanımlanmış olan EY 3 numaralı alet ${ }^{14}$ (Fig.4:7) ise; çizimi sırasında teknik açıdan yanlış yönlendirildiği için uç morfolojisi gösteriyor gibi görünmesine karşın, düzeltileri iç yüzde olan yatay kenar kazıyıcı kategorisinde sinıflandırılmalıdır. Bununla birlikte taşımalığı hiçbir levallois teknik özelliği de içermez. Yonganın yumrusu oldukça iri olup, topuğu düz ve geniştir. Aletin her iki yüzü de flüviyal akıntı, diğer inorganiklerle olan sürtünme ve aşınmalardan dolayı doğal bir şekilde cilalanmıştır. Böylesi yonga üzerine iç yüzde yapılan düzelti tekniğini Güneydoğu Anadolu Bölgesi'nden iyi bilmekteyiz ${ }^{15}$. İç yüz üzerinde yapılan bu düzenli-devamlı düzeltilerin, form açısından değil ancak işlev açısından niteliği biraz tartışmalıdır. Çünkü, özellikle tipik moustérien kültür katmanlarında gördüğümüz düzeltiler, parçanın genellikle üst yüzünde yer almaktadır. Nitekim Anadolu'dan bir örnek verecek olursak; Yalçınkaya'nın Karain Mağarası kenar kazıyıcıları üzerinde yapmış olduğu çalışmaya göre, iç yüzde kenar kazıyıcılar, tüm kenar kazıyıcılar içinde sadece \%2.5 gibi çok düşük bir yüzde göstermesine karşın, üst yüz düzeltisi karşılaşılan en genel teknik olarak ortaya çıkmaktadır ${ }^{16}$.

Yukarıda daha önce yayınlanmaları nedeniyle açıklamalarını daha geniş tuttuğumuz bu 3 alet ile birlikte, bizim bizzat çalıştığımız diğer 7 adet buluntu içinde; bir adet levallois yonga (Fig.5:1), bir adet yontma artığ1 yonga, bir adet merkezcil recurrent levallois çekirdek (Fig.3:3), bir adet kenar kazıyıcı, bir adet dilgi üzerine kenar kazıyıc1 (Fig.6:9) (muhtemelen de Paleolitik Çağ sonrası) ve 2 adet de yöneşen kenar kazıyıcı (Fig.4:2,6) tespit edilmiştir.

\footnotetext{
14 Kansu 1940, 45

15 Taşkıran-Kartal 2004, 717 (şekil 14:3); Taşkıran 2002, 412 (şekil 22:4, 12)

16 Yalçınkaya 1989, 116
} 
Ancak; bu yöneşen kenar kazıyıcılardan bir tanesinin (Fig.4:6) üst yüzündeki negatif izler, tek kutuplu yöneşen levallois yongalama tekniği göstermekte olup, teknik açıdan belki de levallois uç çıkarmak üzere hazırlanmıştır diyebiliriz. $\mathrm{Bu}$ hazırlama sonucunda çıkan yonganın, yonga ekseni ile alet ekseni $45^{0}$ lik bir açı yapmakta olup, uç ve yöneşen kenar kazıyıcı kategorilerinin arasında bir morfoloji göstermiştir. Eğer elimizdeki buluntular yeterince fazla olsayd,, bu buluntu topluluğu içindeki benzer aletlerin indisleri, söz konusu aletin, alet kategorilerinin biri ya da diğeri içinde sinıflandırılabilmesi hakkında bize bilgi verebilecekti. Bu durumda bu alet için kesin bir yargıda bulunmak istemiyoruz.

Etiyokuşu buluntularını genel anlamda özetleyecek olursak; levallois tekniğinin kullanıldığını ve bununla birlikte, moustérien tipte yontmataş aletlerin üretildiğini belirtmek yerinde olacaktır. Ele geçmiş olan kısmi iki yüzeyli alet ise, acheuléen geleneğinin varlığının bir kanıtıdır. Hemdönem olup olmadıklarını bilemediğimiz bu topluluğu, alt Paleolitik'in sonuna ve orta Paleolitik'e bağlamak olanaklıdır.

Etiyokuşu buluntuları hakkında, şimdiye dek dile getirilmemiş olan bir konu da bu buluntuların gerçek konumlarıyla ilgilidir. Kansu'nun yayınından edindiğimiz bilgilere göre söz konusu buluntular, Etiyokuşu buluntu yerinde Çubuk Suyu'nun eski seviyelerine ait olan, çakillı kumlu V. tabakasından ele geçmiştir. Ancak dikkat edilmesi gereken konu ise, bu buluntuların V. seviye içinde depolanmadan önce sürüklenerek buraya gelmiş olmasıdır. Yani "in situ" değillerdir. Dolayısıyla, Etiyokuşu V. tabakaya ait olan yontmataş elemanların kökenini, Çubuk Suyu'nun daha yukarılarında aramak gerekmektedir. Kısacası, bu aletlerin çoğunluğu Etiyokuşu denen yerde üretilmemiş olmalıdırlar. $\mathrm{Bu}$ durumda,
Çubuk Suyu'nun yukarı kesimlerinde, şüpheli de olsa bir "in situ" Paleolitik buluntu yeri saptamak şimdilik olasılık dahilindedir. Nitekim Kökten, bu aletlerin belki de, Keçiören sirtlarından ya da Solfasol Köyü çevrelerinde tespit edilen çakmaktaş1 yumru tarlalarından veya açık bir istasyondan sürüklenerek gelmiş olabileceklerini vurgulamaktadır. Kökten aynı zamanda bu konuya Bittel ve Pfannenstiel'in de değinmiş olduğunu belirtmektedir ${ }^{17}$.

\section{II.4. Keçiören}

Ankara'nın hemen kuzeyinde yer alan Keçiören'in yontmataş buluntuları, ilk kez M. Pfannenstiel tarafindan 1940'li y1llarda tespit edilmişlerdir ${ }^{18}$. Kökten, Ankara çevresindeki hammadde kaynaklarından bahsederken, özellikle Keçiören'i vurgulamış ve şöyle yazmıştır: “....Keçiören sırtları; Çeçtepe köyünden - Beypazarl dolaylarına ulaşan dağların mühim bir kisml, ve buraları çevreliyen yüksek sekilerin üstleri;

çakmaktaşı yumru tarlaları tabii kaynaklarımız arasındadır" ${ }^{\prime 19}$. Kökten'den edindiğimiz bu bilgiye göre, Keçiören çakmaktaşı yatakları açısından oldukça zengin görünmektedir.

Pfannenstiel'in ardından yine aynı alanda 1948 y1lında bu kez, Fikret Ozansoy toplama yapmıştır. Araştırmacının yayınından elde edinilen bilgiler doğrultusunda, buluntular genelde dağınık olarak ele geçtiklerinden ötürü, bu alanda kesin bir yerleşim yerinden bahsetmek yanlış olacaktır. Kansu ve Ozansoy'un yayınına göre, Keçiören'in kuzeyindeki andezit bir taban üzerinde $50 \mathrm{~m}^{21}$ lik bir alandan birçok alet ele geçmiştir. Burada ayrıca, micoquien tip balta ve baltacıklar ile kırık olmakla birlikte, oval

17 Kökten 1952, 183

18 Harmankaya-Tanınd1 1996

19 Kökten 1952, 181 
ve üçgen biçimli iki yüzeyli aletler ve levalloiso-moustérien tipte kazıyıcı ve uç bulunmuştur $^{20}$.

Anabilim Dalı koleksiyonu üzerinde bizim yapmış olduğumuz çalışmaya göre, Keçiören buluntuları tipolojik olarak oldukça çeşitlilik göstermektedir. Koleksiyonda toplam 13 adet olan bu yontmataş elemanlar; 3 adet levallois çekirdek, 1 adet prizmatik çekirdek, 3 adet yonga ile l'er adet iki yüzeyli alet, kenar kazıyıcı, dişlemeli alet, çontuklu alet, uç ve bir de tanımlanamamış kırık alet olarak özetlenebilir.

Keçiören buluntuları, morfolojik açıdan oldukça tipik örneklerden oluşmaktadır. İki yüzeyli alet (Fig.2:1), boyut olarak oldukça küçük olup, iyi bir simetri gösterir. Her iki yüzündeki kabuk kalıntısı, aletin kenar kısmında bulunmaktadır. Çıkarımları sı ̆̆, profili hafif bir zig-zag gösterir. Doğal işleyişten ötürü oldukça cilalanmıştır. Dolayısıyla çok sürüklenmiş olan bu alet in situ değildir. Bütün bu özelliklerinden ötürü, alt Paleolitik'in son aşamaları ve belki de erken orta Paleolitik döneme bağlanabilir.

Keçiören'in çekirdek buluntuları arasında, 3 adet tipik levallois çekirdek ve bir de büyük bir olasılıkla Paleolitik dönem sonrasına ait olan prizmatik tip dilgi çekirdeği vardır. Levallois çekirdeklerden birisi "lineal", diğeri "iki kutuplu recurrent" ve üçüncüsü "merkezcil recurrent" tip levallois çekirdektir. Lineal tip ya da diğer bir deyişle klasik levallois çekirdek (Fig.3:6) oldukça tipiktir. Üzerinde bazı yanma izleri tespit edilmiştir. Merkezcil hazırlanmış olup, her iki yüzünde de kabuk bulunmaz. Vurma düzlemi yüzcüklüdür. İki kutuplu recurrent levallois çekirdek olan diğer levallois çekirdek (Fig.3:2) de üst yüzde ve vurma düzlemlerinde iyi bir hazırlama izi gösterir.

${ }^{20}$ Kansu-Ozansoy 1952, 383,384
Arka yüzü kabuklu ve hammaddenin doğal yüzeyini taşımaktadır. Merkezcil recurrent levallois çekirdek (Fig.3:9), lineal tip levallois yontma zincirinin uygulanmasinın ardından yongalama işleminin devam etmesiyle recurrent tip özelliğini almıştır. Çekirdeğin arka kısmı iyi hazırlanmıș olup, merkez kısmında kabuk taşımaktadır. Lineal levallois çekirdek safhasında, vurma düzleminin yüzcüklendiği halen görülebilmektedir. $\mathrm{Bu}$ tekno-tipolojik özelliklerinden ötürü, Keçiören'in levallois çekirdeklerini görece orta Paleolitik döneme bağlamak mümkündür.

Prizmatik çekirdek ise (Fig.6:1); tek kutuplu olup, vurma düzlemi yenilenme izi gösterir. Çekirdeğin her iki kenar kısmında da tepe hazırlaması yapılmış, ancak tepeli parça (dilgi) alınmamıştır. Çekirdeğin alt kısmı kırılmış ve belki de bu yüzden terkedilmiştir. Teknik ve tipolojik açıdan, Anadolu'dan iyi bilinen çanak çömleksiz Neolitik dönem ve sonrasında görülen dilgi çekirdeklerine yaklaşmaktadır.

Yonga üzerine işlenmiş aletler açısından orta Paleolitik dönemin erken safhalarına tarihleyebileceğimiz bir adet uç (Fig.5:5) oldukça tipiktir. Taşımalığı kalın bir yongadır. Dorsal yüzün merkez kısmında uzunlamasına bir kabuk kalıntısı vardır. Düzeltileri basamak pulcukludur. Bu haliyle uç oldukça iyi korunmuş olup, alet ekseni ve yonga ekseni aynı doğrultudadır. 1 adet kenar kazıyıcı alet içbükey morfoloji göstermektedir (Fig.4:4). Levallois yonga üzerine yapılan bu aletin dorsal yüzü iki kutuplu hazırlama tekniği içermektedir. $\mathrm{Bu}$ özelliklerinden ötürü orta Paleolitik döneme bağlanabilir. 1 adet düzeltili çontuklu alet ise, levallois olmayan bir yonga üzerine yapılmıştır. Alet, çontuk genişliği açısından iri çontuklu kategorisine girmektedir. Yukarıda adı geçen dişlemeli alet ise, 
oldukça sürüklenmiş olduğundan tüm yüzeyi cilalanmıştır. Çok tipik bir örnek olmayıp, kaba dişlemeli bir morfoloji göstermektedir. Diğer bir düzeltili parça ise, tanımlanamamış ve proksimal kısmı kırık bir alettir (Fig.4:3). Taşımalığı yonga olup, pulcuklu düzelti taşımaktadır. Orta Paleolitik döneme tarihlenebilir.

Diğer buluntulardan 3 adet çakmaktaşı yonga arasında, bir tanesi atipik levallois yonga özelliği göstermektedir. Diğer ikisi ise, hazırlanmamış çekirdeklerden çıkarılmış ve işlenmemiş buluntulardır.

\section{II.5. İlhan Çayı}

Burası Ankara il merkezinin batısında, Ayaş ilçesinin $12 \mathrm{~km}$ kadar kuzeybatısındaki İlhan Köyü'nün kuzeyindedir. Buluntu alanı ise İlhan Çayı'nın sekileridir. İlk olarak 1945 yılında İ.K.Kökten, Ankara yöresi yüzey araştırmalarında buradan Paleolitik Çağ'a ait aletler toplamıştır ${ }^{21}$. Kökten, daha sonra 1951 yılında Işıklar, Alpay ve Ozansoy ile birlikte bu alanlardan yonga aletler bulmuşlardır. Buradan ele geçen ve Kökten tarafindan bazalt bir elbaltası diye nitelenen aletin $^{22}$, Taşkıran tarafından gerçekte iri bir yonga alet olduğu ortaya konmuştur ${ }^{23}$. Diğer ele geçmiş olan aletler ise, Kökten'e göre levalloiso-moustérien tipte kazıyıcılardır ${ }^{24}$. Kökten, aynı yayınında Güdül çevresinde Kirmir Vadisi'ne bakan platolar üzerinde de levalloiso-moustérien tipte aletler olduğunu belirtmektedir ${ }^{25}$.

Anabilim dalı koleksiyonunda yer alan 1 adet levallois yonga üzerine yapılmış olan tek dışbükey kenar kazıyıcı (Fig.4:5) çok

21 Kökten 1947a, 224; Kökten 1947b, 441

22 Kökten 1947b, 444

23 Taşkıran 1990, 38

24 Kökten 1947b, 444

25 Kökten 1947b, 444 tipik bir alettir. Hammaddesi çakmaktaşıdır. Dorsal yüzünde merkezcil levallois hazırlama izleri görülmektedir. Topuğu yüzcüklüdür. Tipik moustérien kültüre aittir ve dolayısıyla orta Paleolitik döneme tarihlenebilir.

\section{II.6. Sindıran-Yanıktarla}

Literatürde adına rastlayamadığımız bu buluntu yerine ait materyaller, Kökten tarafından kurulmuş olan Prehistorya kürsüsü koleksiyonuna kazandırılmıştır. Üzerinde çalışmış olduğumuz 5 adet yüzey buluntusu, teknik ve tipolojik açıdan orta Paleolitik ve orta Paleolitik sonuna işaret eden kriterler göstermiştir.

$\mathrm{Bu}$ grup içerisinde; hemen hemen tükenmiş ve çontuklu alet haline dönüştürülmüş bir disk biçimli çekirdek (Fig.5:4), levallois yonga üzerine yuvarlak ön kazıyıcı (Fig.5:3) ki bu alet muhtemelen üst Paleolitik tiplere yaklaşmaktadır, prizmatik çekirdekten alınmış bir çekirdek tablası (Fig.6:4) ki bu parça da daha sonradan iç yüzünde yapılan düzeltiler sonucunda yatay kenar kazıyıcı olarak modifiye edilmiştir (muhtemelen üst Paleolitik ve sonrası dönemlere tarihlenebilir), erken orta Paleolitik döneme ait olduğunu düşündüğümüz kalın kenar kazıyıcı (Fig.4:1) ve bir de yonga, SindıranYanıktarla koleksiyonunu teşkil etmektedir.

\section{II.7. İvedik Köyü}

Burası Ankara il merkezi içerisinde, Yenimahalle Belediyesi sinırlarında bir buluntu yeridir. Literatürde pek de ad1 geçmemesine karşın, Prehistorya Anabilim Dalı koleksiyonu içerisinde yer alan buluntular toplam 3 adettir. Bu 3 buluntudan birisi, tașımalığ 1 kalın levallois yonga olan ikili alettir (Fig.5:2). Bu alet, aslında her iki 
kenarında da çontuk taşıyan bir ön kazıyıcı alettir. İç yüzün proksimal kenarının birinde küçük çıkarımlarla inceltme yapılmış ve dolayısıyla taşımalığın yumrusu hemen hemen kaldırılmış durumdadır. Ön kazıyıcı alnı oldukça ince düzeltiler taşımaktadır. Gerek teknik, gerekse tipolojik açıdan orta Paleolitik döneme tarihlenebilecek bir buluntudur. İvedik Köyü'nden ele geçen diğer iki buluntu da levallois teknik işçiliği göstermekte olup, bunlardan birisi levallois uçtur (Fig.5:6).

\section{II.8. Ergazi}

Ord. Prof. Dr. Şevket Aziz Kansu, Ergazi'deki buluntuların ilk olarak 1938 yılında, Dr.Afet İnan ve Profesör E.Pitteard tarafindan bulunduğunu ve bu buluntuların kendi deyimiyle "levalloiso-moustérien" tipte olduğunu bildirmektedir ${ }^{26}$. Kökten ise; Ergazi'nin 1937 yilında Pittard, İnan ve Pfannenstiel tarafından araştırıldığını bildirmekte ve bu buluntu yerinin İç Anadolu Bölgesi'nin Etiyokuşu'ndan sonra orta Paleolitik dönemini açıklayan ikinci yer olduğunu vurgulamaktadır ${ }^{27}$.

İncelemesini yapabilmiş olduğumuz Ergazi buluntularının, yukarıda da açıklamış olduğumuz üzere, oldukça eski olan Prehistorya Anabilim Dalı koleksiyonu içerisinde 3 ayr1 alandan ele geçmiş gibi etiketlenmiş olması, bizi de aynı şekilde ayrı ayrı inceleme gerekliliğine yöneltti. Ergazi etiketli 2 adet yüzey buluntusundan biri, merkezcil recurrent levallois çekirdek; diğeri ise, tek kutuplu recurrent levallois çekirdektir. Her ikisi de; çok tipik olmamakla birlikte, Ankara'nın genel görünümü içinde tipik buluntularındandır diyebilir ve bunları kabaca orta Paleolitik döneme bağlayabiliriz.

${ }^{26}$ Kansu-Ozansoy 1952, 381

27 Kökten 1947b, 435

\section{II.8.a. Ergazi-I}

Toplam 3 adet yüzey buluntusundan oluşan Ergazi-I buluntularından ikisi, oldukça tipik olan ve çok iyi hazırlama tekniği içeren levallois çekirdeklerdir. Bunlardan birisi, klasik levallois çekirdek (Fig.3:5); diğeri ise, merkezcil recurrent levallois çekirdektir (Fig.3:7). Üçüncü buluntu da çok tipik olmayan bir levallois çekirdeğe aittir.

\section{II.8.b. Ergazi-II}

Söz konusu koleksiyondaki Ergazi-II yüzey buluntuları da 3 adet olup, özel tiplerle temsil edilmişlerdir. Bunlardan bir tanesi merkezcil recurrent levallois çekirdektir (Fig.3:1). Bu çekirdeğin, her iki yüzü de oldukça titiz bir hazırlama evresi geçirmiştir. Çekirdeğin arka yüzünde çok az bir kabuk kalıntısı vardır. $\mathrm{Bu}$ çekirdeği de orta Paleolitik döneme atfedebiliriz. Buluntulardan bir diğeri ise, kırık olmakla birlikte muhtemelen bir levallois uçtur (Fig.5:8). Topuğu yüzcüklü olup, çok iyi hazırlanmış bir vurma düzlemi teknolojisine sahiptir. Mevcut kısmında bir düzelti izine rastlanmamıştır. Orta Paleolitik dönem karakterlidir. Doğal olarak cilalanmış olması oldukça sürüklenmiş olduğunun bir göstergesidir. Ergazi-II'ye ait son olarak, dorsal yüzü tek kutuplu çıkarım gösteren bir dilgimsi yonga (Fig.6:2) dikkat çekicidir. Muhtemelen tek kutuplu bir prizmatik çekirdekten çıkarılmış olan bu parça üzerinde hiçbir düzeltiye rastlanmamıştır. Dönem olarak kesin birşey söylemek çok zor olsa da, teknik ve tipolojik açıdan orta Paleolitik dönem sonrasına ait olması gerekir diye düşünebiliriz.

\section{II.9. Etimesgut}

Ankara'nın batısında ve bugün için merkez ilçe konumundadır. Literatürde Etimersgut'a ait buluntulardan pek bahsedilmemekle 
birlikte, incelemesini yapmış olduğumuz 3 buluntu içerisinde bir tanesi tipik olan merkezcil recurrent levallois çekirdektir (Fig.3:8). Arka yüzü hazırlanmış olmakla birlikte hammaddenin doğal yüzünü de içerir. Doğal cilalanma izi oldukça sürüklenmiş olduğunu gösterir. Diğer iki buluntu da merkezcil recurrent levallois çekirdek olup, çok tipik değildir. Etimesgut buluntuları teknik ve tipolojik açıdan orta Paleolitik döneme bağlanabilir.

\section{II.10. Çayyolu Sondurak Çevresi}

Burası da yine Ankara'nın batısında bir buluntu yeridir. Ele geçen yontmataş malzeme çok geniş bir zaman aralığına yerleştirilebilir. Yeni ele geçen bu buluntular, aslında, Ankara'nın eski buluntularını bir anlamda destekleyen ve bir anlamda da yenilikler sunan bir görünüm sergilemiştir.

Çayyolu Sondurak buluntularının en ilginç olanları, toplam 2 adet ve alt Paleolitik döneme tarihleyebileceğimiz birisi klasik iki yüzeyli ve diğeri nacak olan aletlerdir. Bunlardan klasik iki yüzeyli olan alet (Fig.2:3), orta kenar kısmında eski bir kırık taşır. Profili zig-zaglıdır. Çıkarımları çok da sı ğ olmayıp, orta büyüklüktedir diyebiliriz. Diğer buluntu olan nacak (Fig.1:1) ise, dip kısmında hammaddenin doğal yüzeyini taşır. Her ikisi de genel anlamda alt acheuleen tip aletlerdir.

Yukarıda görüldüğü gibi, eski buluntulara dair genellikle levallois teknolojisinden ve buluntularından bahsettik. Aynı durum yeni buluntularla da varlığını teyit etmiş gibi görünüyor. Buluntulardan bir tanesi, ucu kırık olmakla birlikte çok iyi işçilik gösteren bir levallois uçtur (Fig.5:7). Topuğu yüzcüklü olup, dorsal yüzü klasik "Y" nervürü gösterir. Kanımızca orta Paleolitik dönemin iyi bir örneğini teşkil eder.
Bir diğer buluntu dönümlü dilgidir (Fig.6:3). Dorsal yüzünde dilgi negatifleri ve çok az bir kısmında da kabuk kalıntısı içerir. Teknolojik açıdan tek yönlü çıkarımlar içeren prizmatik bir çekirdekten çıkarılmış olmalıdır. Böylesi yan ürünler, Anadolu'nun üst Paleolitik ve Epi-paleolitik dönemlerinde oldukça yaygın ele geçmiştir. Bu bakımdan Paleolitik sonuna tarihlenebilecek bir buluntudur diyebiliriz. Yine Paleolitik Çağ sonuna tarihleyebileceğimiz bir buluntu ise, dilgimsi kalın yonga üzerine işlenmiş ön kazıyıcı alettir (Fig.6:7). Parçanın dorsal yüzünde dilgimsi negatif izler vardır. Kazıyıc1 alnı proksimaldedir ve düzeltiler diktir. Ancak, taşımalığın iç yüzünde de, hem kenar hem de alın kısmında yarı dik düzeltilerle düzenleme yapılmıştır. Bu yapısıyla, aletin bir bıçak gibi de kullanılmış olma olasılığı mümkün görünmektedir.

Ele geçmiş olan 1 adet orak dilgi (Fig.6:6), gerçek anlamda tarım toplumuna ait olabilecek tek parçadır. Proksimal ve distal kısımları kırıktır. Kenarlarında kullanım çentikleri olup, tek kenarı silika parlaklığı içerir. Stratigrafik kontekst içinden ele geçmediği için kesin dönemini vermek mümkün değildir.

Çayyolu Sondurak buluntularından olan son 2 buluntu, çok tipik olmayan birisi şekilsiz çekirdek ve diğeri bir yonga olan kabaca Paleolitik teknoloji içeren yontmataş parçalardır.

\section{II.11. Eryaman}

Toplam 7 adet olan Eryaman buluntular1 içerisinde, 2 tanesi oldukça önemlidir. Bunlardan birisi, neredeyse abbevilien tipte olabilecek ve alt Paleolitik dönemin erken safhalarına tarihleyebileceğimiz bir klasik iki yüzeyli alettir (Fig.1:2). Geniş zig-zag profilli olan bu aletin her iki yüzeyindeki çıka- 
rımlar oldukça iri ve derindir. Üzerinde hiçbir kabuk kalıntısı yoktur. İkinci önemli buluntu ise, atipik iki kutuplu recurrent levallois çekirdektir (Fig.3:4). Arka yüzünde hiçbir hazırlama izi göstermez. Üstelik, üst yüzün bir kısmında kabuk kalıntısı da mevcuttur. Hazırlama izi, üst yüz ve özellikle de vurma düzleminde göze çarpar. $\mathrm{Bu}$ özelliğiyle; son yıllarda Güneydoğu Anadolu Bölgesi'nde yapılan Ilısu Baraj Gölü Alanı Paleolitik Çağ yüzey araştırmalarından ele geçen yarı hazırlanmış çekirdekler tarzında bir teknolojiye sahiptir. Genel anlamda alt Paleolitik sonu orta Paleolitik başlarına tarihlenebilecek bir tipoloji ve teknoloji içerir.

Diğer buluntular arasında, 1 adet klasik levallois çekirdek çok tipiktir ve iyi bir işçilik gösterir. Bununla birlikte; bir adet atipik levallois çekirdek, bir adet şekilsiz çekirdek ve 2 adet dilgi ise, orta Paleolitik döneme bağlanabilecek özellikler sergilemiştir. Ancak, dilgilerden birisi tipolojik olarak orta Paleolitik sonu-erken üst Paleolitik döneme tarihlenebilir.

\section{TARTIȘMA ve SONUÇ}

Açıkça söylemek gerekirse, eski bilim duayenlerimizin zor şartlar altında ne çok iş yapmış olduklarını anlamak bizi çok etkiledi. Zamanın bilgi ve koşullarına karşın, çeşitli yorumlar ve çıkarsamalar yapılmış ve bu verilerin günümüze aktarılmış olunması dikkate değerdir. Her birini saygıyla anıyoruz.

Birçok prehistoryenle yaptığımız çalışmalar ve konuşmalar sırasında, Güneydoğu Anadolu Bölgesi hariç, Anadolu'nun iki yüzeyli aletler açıssından yoksun olduğu kanısı hemen herkesce kabul edilen bir görüş olarak ortaya çıkıyordu. Bu yaklaşım ise; klasik iki yüzeyli ya da eski deyimiyle elbaltası geleneğinin, Anadolu'nun iç bölgelerinden değil de, Kafkaslar boyunca ilerlerdiği fikrini gündeme getiriyordu. Aslında, o sıralarda bu hipoteze pek de karş1 çıkabilecek yeterli stratigrafik kanıtımız da yoktu. Dolayısıyla da, söz konusu görüşlere bilinçsizce müdahale etmek, bilimsel bir yaklaşım olarak görünmüyordu. İki yüzeyliler hakkında bilinen bir başka hipotez de, Movious tarafindan gündeme getirilmiş ve "Movious Line" olarak adlandırılmıştır ${ }^{28}$. $\mathrm{Bu}$ hatta göre; İngiltere'nin güneydoğusundan Hindistan'a kadar olan bir yılankavi çizgi, acheuléen geleneğinin sınırlarını oluşturmuştur. Buna göre; İç Anadolu Bölgesi tam olarak ikiye ayrilmakta ve dolayısıyla, İç Anadolu Bölgesi'nin Ankara'nın da bulunduğu kuzey kesimi acheuléen geleneği açısından fakir görünmektedir. Açıkcası bu doğru da olabilir yanlış da. Pratikte ve aslında problem, İç Anadolu Bölgesi'nde sistemli ve yeni "prehistorik arkeoloji" araştırmalarının yapılmamış olmasından kaynaklanmaktadır. Çünkü çok yakın zamanlarda Prof.Dr.Nur Balkan Atl, uzun zamandır araştırmalarını yapmakta olduğu Göllüdağ çevresinde, stratigrafik konumu içinde bir adet klasik iki yüzeyli alet bulmuştur. Bu buluntu, aslında tek başına zayıf da olsa benimsenmiş olan görüşe karşı bir kanıt teşkil etmektedir. Şu halde, daha önce yazmış ve açıklamış olduğumuz ve yüzeyden ele geçen klasik iki yüzeyli aletleri de dikkate alırsak, elimizdeki kanıtların günden güne arttığını belirtmek, yeni yaklaşımları ve hipotezleri de beraberinde getirecektir.

Umarız ki; özellikle stratigrafik açıdan bu klasik iki yüzeyli aletlerin sayısı çoğalır ve gerçekte Anadolu'nun iç bölgelerinin Prehistorik geçmişi literatürde yerini bulur. Bulur derken, yapılması gerekenlerin bilincinde olunması da gerekecektir. Kesin bir şekilde belirtmek isteriz ki, Anadolu'da günümüzde yapılan alt Paleolitik dönem çalışmaları, bir elin parmaklarını geçemeyecek kadar azdır. Nedenleri tartışlabilir.

${ }^{28}$ Movious 1944; Movious 1948 
Ancak, konumuzun bu olmadığının da bilinciyle, İç Anadolu Bölgesi'nde gelecekte böylesi buluntuların artabileceğini ve yeni hipotezlerin gelişebileceğini, şimdiden kaçınılmaz bir gerçek olarak düşünüyoruz.

Ankara'da klasik iki yüzeyli aletler açısından eski buluntulardan Keçiören ve Etiyokuşu kanıtları ile yeni buluntulardan Çayyolu Sondurak Çevresi ve Eryaman buluntuları önemli bulgulardır. Toplam 5 adet olan bu yontmataş aletler elbette ki çok şeyi açıklayamaz, ancak birçok şeyin de müjdecisi olabilirler. Bunlara ek olarak, bizim bu çalışmayı yaparken literatürden varlığı bilinen ve ulaşamadığımız bazı iki yüzeyli aletlerin varlığını da eklemek ve vurgulamak yerinde olacaktır ${ }^{29}$.

1999 yllında Profesör Otte ve diğer saygın bilim adamlarıyla yapmış olduğumuz bir yayında, Ankara hakkında birkaç iki yüzeyli aletten bahsetmiştik ${ }^{30}$. Bugün bu sayının az ancak yavaş da olsa artıyor olmasi; böylesi buluntuların olmadığı anlamından öte, yeterli düzeyde "Paleolitik Çă Arkeolojisi” araştırmalarının eksikliğini belirtir nitelikte anlaşılmalıdır. Unutmamamız gereken bir başka buluntu grubu da, Torosların güneyindeki Karain Mağarası klasik iki yüzeylileridir. $\mathrm{Bu}$ buluntular, Profesör Kökten'in kazılarından ele geçmiştir. Stratigrafinin bugünkü konumunda tam olarak neresinden ele geçtiğini bilmediğimiz bu aletlerin, hangi kültür grubu içerisine yerleştirilmesi gerektiği henüz tartışmalıdır. Acaba güneyle ilgili bir kültür kompleksine mi yoksa daha başka alanlarla $\mathrm{m} 1$ ilişkiliydi? Bunu henüz bilemiyoruz. Bununla birlikte, Niğde Göllüdağ'da stratigrafiden ele geçen klasik iki yüzeyli aletin önemi çok büyüktür. Çünkü bugün için tarihlendirilmesi yapılabilecek tek örnektir.

\footnotetext{
29 Bu konu hakkında detaylı bilgiler için bkz.: (Taşkıran 1990); (Taşkıran 1998); (Kökten 1953).

30 Otte ve diğ. 1999, 75
}

Balkan Atlı'dan edindiğimiz bilgiler dahilinde, ele geçmiş olan bu klasik iki yüzeyli aletin çıkmış olduğu seviyenin oldukça üst katmanlarından yapılan bir yaşlandırmanın, 200.000 yıldan daha eski olduğunu öğreniyoruz $^{31}$. Bu sonuç, iki yüzeyli aletin çok daha eski tarihler verebileceği anlamına gelmektedir. Bu konuda, tarih açısından tahmini birşey vermek çok spekülatif olacağından herhangi birşey söylemekten kaçınıyoruz.

Öte yandan tezat oluşturabilecek bir diğer konu da şudur; Ankara'nın klasik iki yüzeyli aletleri, Güneydoğu Anadolu Bölgesi'nin gelişkin klasik iki yüzeyli aletlerinden teknik açıdan farklıdır. Ankara buluntuları biraz daha kaba ve arkaik karakterler göstermektedir. $\mathrm{Bu}$ durumda karşımıza bazı sorular çıkmaktadır: Ankara buluntuları Güneydoğu Anadolu Bölgesi klasik iki yüzeylilerinden eski midir? Ĕger eskiyse kökeni neresidir? Bu soruların cevabı sanırız şimdilik kaydıyla gelecekteki çalışmalara gebedir.

Çalışmamız sırasında karşılaştığımız ikinci ve önemli bir konu da, özellikle eski araştırmalarda karşımıza çıkan "levalloisomoustérien" terimi olmuştur. Aslında bu terim, eski araştırmaların birçoğunda oldukça yaygın kullanılmıştır. Ankara buluntuları açısından elimizdeki verilere dayanarak levallois teknolojisinin varlığını inkar etmek mümkün görünmemektedir. Üstelik bu tekniğe ilişkin oldukça başarılı örnekler de vardır. Ancak, söz konusu tekniğin orta acheuléen'den itibaren başlayan bir teknik olduğunu da gözden kaçırmamak gerekmektedir. Bununla birlikte; levallois taşımalıklar üzerine pulcuklu ve/veya basamak pulcuklu düzeltilerle kenar kazıyıcı aletlerin varlığ $1 \mathrm{da}$ dikkat çekici olup, bir anlamda moustérien kültür izlerine de rastlanmıştır. Böylesi aletlerin varlığı, hem tipik moustérien hem de charentien tip aletlerin Ankara'daki yüzey buluntusu kanıtlarını teşkil ederler.

31 Nur Balkan Atlı ile kişisel görüşme 
Bilindiği üzere, Karain Mağarası'nın orta Paleolitik seviyeleri de, hem "Karain tip moustérien" ya da "Toros-Zagros tip moustérien", hem de bunun hemen altında yer alan charentien kültür komplekslerine ait kalıntılar içermektedir ${ }^{32}$. Buna benzer kanıtların Ankara'dan da ele geçmiş olması belki de, güneybatı Anadolu ile olabilecek olası ilişkileri gündeme getirecektir. Ancak bu saptamamız, Ankara'nın söz konusu tip buluntularının levalloiso-moustérien olarak adlandırılması gerektiği anlamına da gelmemelidir. Bu durumda bizce, levallois tekniği ile birlikte moustérien aletlerin de varlığını ve bu buluntulara charentien tarzda aletlerin de eşlik ettiğini belirtmemiz gerekir. $\mathrm{Bu}$ konudaki problemimiz ise, adı geçen bu komplekslerin tarihlerinin henüz bilinmiyor olmasıdır. Her bir durumda, hepsinin de yüzey buluntusu olması tipolojik tarihlendirmenin ötesine gidemememize neden olmaktadır.

Aurignacien terimi de, eski araştırmacılar tarafından kullanılmış bir kültür kompleksi olarak karşımıza çıkmıştır. Görünen odur ki, bu görüşü ve aurignacien'in varllğğnı Anadolu için kabul etmek doğru bir saptama olacaktır. Elimizdeki veriler de bunu desteklemektedir. Ancak unutulmaması gereken konu, ister Ankara yöresi ister Anadolu'nun diğer bölgeleri olsun, üst Paleolitik dönemin Yurdumuzda hala tam olarak açığa kavuşamamış bir problem olmasıdır ${ }^{33}$.

Başka yazılarımızda da belirtmiş olduğumuz gibi, bir diğer tartışmalı konu da Mezolitik Çağ bilmecesidir. Bu sorun sanırız bir müddet daha karşımıza çıkmaya devam edecek. Bu durumda sorulacak soru çok basittir: Anadolu'da Mezolitik Çağ ve/veya Mezolitik yaşam tarzı var mıdır, yok mudur? Konumuzun biraz dışında olmasından ötürü bu tartışmayı burada açmaktan kaçınıyoruz.

32 Otte ve diğ. 1999: 75, 77

33 Daha detaylı bilgi için bkz. (Özçelik 2003).
Ancak, bu tartışmaya yönelik çalışmaların da varlığını belirtmek isteriz ${ }^{34}$. Mezolitik teriminin tartışılması bir yana, Mezolitik Çağ'a ait olan tardenoasian kültüre ilişsin bir takım yazılarla karşılaştık. Bu kültürün Anadolu'da 20.yy'ın ortalarında ortaya atılmış olmasının nedeni, Ankara Macunçay sekilerinde ortaya çıkan mikrolitler ve mikroburinlerden kaynaklanmıştır. Bu mikrolitlerin çoğunluğunun trapez biçimli olması ve mikroburinlerin varlığı gerekçe gösterilerek, Avrupa'nın Mezolitik Çă̆ tardenoasian kültürüne odaklanılmış olunması, günümüzde bir anlamda paradoks yaratmaktadır. Kansu bir yayınında şöyle yazmıştır: "Şu hakikat de malûmdur ki, (micro-burin'ler Tardenuvaziyen endüstride mevcut olmakla beraber, yokluğu bu endüstrinin Tard. olamıyacağına delâlet edemez ve fakat varlığl, o kültürün Tard. olduğunu derhal tayin eder (Burkitt, s.157) Gerçekten MicroBurin'ler bu kültürün bir remzidir (Clark s.203, 1936). Macun çayı mikrolitleri içinde 20 den fazla bu pigme-burin'lerin bulunuşu, bu kültür bakiyelerinin Ankara Mesolitik Tardenuvaziyen kültürünün varlı̆̆ını ispata yetebilir" $^{35}$. Oysa bugün mikroburinlerin bol miktarda ele geçtiği birçok Levant ve/veya Zagros kültür kompleksleri ile karşı karşıyay1z. Nas1l bunlara tardenoasian diyemeyeceksek, Ankara mikrolitik buluntu topluluklarına da temkinli yaklaşmak gerekmektedir. Ayrıca, adı geçen bu mikrolitlerin birine dahi ulaşılamamış olunması, bu tartışmayı temelsiz bir platforma oturtmaktadir. Bu durumda söyleyebileceğimiz hemen her şeyin de spekülatif olması kaçınılmaz bir gerçektir. Değil Ankara, yukarıda da belirtmiş olduğumuz gibi Anadolu'da Mezolitik Çağ'ın varlığı ya da yokluğu, henüz yeni bir gündemle ortaya çıkmaya başlamıştır. $\mathrm{Bu}$ gündem, özellikle de Anadolulu araştırıcılar tarafindan irdelenmektedir. $\mathrm{Bu}$ konuda İstanbul Üniversitesi Öğretim Üyesi olan

${ }^{34}$ Kartal 2003

35 Kansu-Ozansoy 1952, 390 
Prof. Dr. Mehmet Özdoğan'ın da söylemleri vardır $^{36}$. Kendisi bu konuda; özellikle Ağaçlı buluntularının Öküzini buluntularından tipolojik olarak farklı olduğunu belirtmekle ${ }^{37}$ birlikte, Öküzini mağarası tardiglasiyer dolgularının Mezolitik bir yerleşim olup olamayacağının da düşünülmesi gerektiğini vurgulamaktadır $^{38}$. Ancak şimdiye kadar yapılmış olan çalışmalar sonucunda, Öküzini için artık gerçek bir Epi-paleolitik Dönem yerleşim yeridir demek sanırız çok daha doğru bir yaklaşım olacaktır ${ }^{39}$. Çünkü, Ağaçlı ya da Marmara Bölgesi’ndeki benzer yontmataş tipolojiler gösteren yerleşimlerin daha çok batı Anadolu geleneğine ait olduğunu düşünmekteyiz. İşte bu noktada, İç Anadolu Bölgesi ve özellikle de Ankara'nın mikrolitli endüstrilerinin hangi kültür bölgesi grubuna girdiği gerçek bir sorun olarak ortaya çıkmaktadır. Kansu ve Ozansoy'un bulduğu Macunçay mikrolitlerinin nerede olduğu hakkında bir fikrimiz olmadığından dolay1, bu konuya gerçekçi bir çözüm bulmak da şimdilik imkansız görünmektedir. Bu durumda, Anadolu'da (Türkiye Cumhuriyeti topraklarındaki Trakya dahil) gerçek Mezolitik Çağ'ın varlığ 1 ya da yokluğu in situ bir stratigrafik katlaşımdan ortaya çıkacak buluntulara bağlıdır. Böylesi bir yerleşimin saptanabilmesi çok önemlidir. Açıkçası, eğer Anadolu'da gerçek bir Mezolitik yerleşim var ise, bunun hemen hemen Çanak Çömleksiz Neolitik dönem ile çağdaş olabilecek konar-göçer gruplarda aranması gerekebileceğini ve özellikle de kuzeybatı Anadolu'da olabileceğini düşünmekteyiz. Çünkü Mezolitik yaşam tarzı; insanın, özellikle kuzey yarı küre ortası ve kuzeyinde (Avrupa'nın Akdeniz kıyı şeridi ve kuzeyi dahil), buzulların erimesi ile ortaya çıkan yeni ekolojik şartlara adaptasyonudur şeklinde özetlenebilir. Dolayısıyla,

36 Özdoğan 1999

37 Özdoğan 1999, 210

38 Mehmet Özdoğan ile kişisel görüşme

39 Kartal 2003 böylesi bir yaşam tarzı da olasılıkla, belki bat1 Anadolu ya da kuvvetle kuzeybat1 Anadolu içinde olmalıdır. Eğer bu konuda yanılıyor isek; batı ve kuzeybatı Anadolu avc1-toplayıcı geleneğinin ve kültürel buluntularının, Holosen başlangıcında bütünüyle doğuyla aynı olması gerekmez miydi? Oysa ki şimdilik durum bunun tam aksi yönünde görünüyor. Özdoğan'ın tespit etmiş olduğu geç pleistosen Marmara Bölgesi yüzey buluntuları bunun en güzel kanıtlarını sergilemektedir. Bu buluntuların da tarihlendirilebileceği bir in situ yerleşim yerine rastlamak, tabiri yerindeyse "kapıyı aralamak" anlamına gelecektir. Söylemlerimiz tartışmaya açıktır ve bunun tam aksi de iddia edilebilir.

Öte yandan J.Kozlowski, G.Ö. 12.000 ile 10.000 yılları civarında Öküzini'ni de içine alacak biçimde batı Anadolu'nun tıpkı Balkanlar'da olduğu gibi Akdeniz Epigravetien'i içinde olduğunu savunmaktadır. Söz konusu araştırıcının vermiş olduğu haritaya göre, iç Anadolu ve özellikle de Ankara bunun dışında kalmakta ve tamamıyla bilinmeyenleriyle dolu bir alan olarak gösterilmektedir ${ }^{40} . \mathrm{Bu}$ durumda İç Anadolu Bölgesi için yapılması gereken en önemli şey, özellikle geç pleistosen-erken holosen dönemlere ilişkin çalışmaların yoğunlaştırılmasi olacaktır. Aksi taktirde sadece yayınlardan bildiğimiz Macunçay mikrolitlerinin açılanabilmesi mümkün görünmemektedir. Ancak, Kozlowski'nin söylemine göre, biraz önce de belirtmiş olduğumuz gibi özellikle batı Anadolu, güneydoğu Avrupa ile ilişkili görünmekte ve bizim savımızı da kuvvetlendirmektedir. Yani bir anlamda ilişkilerin doğuyla değil batıyla olduğu desteklenmektedir.

İç Anadolu Bölgesi hakkında edindiğimiz son bilgiler, Epi-paleolitik Dönem'e ilişkin kanıtların yoğunlaştı̆̆1 yönünde olmuştur. Baird'in Çatalhöyük'ün güneydoğusunda yer

40 Kozlowski-Kaczanowska 2004, 14-15 
alan Pınarbaşı'nda yapmış olduğu kazılar, M.Ö. 12.000 ile M.Ö. 9.000 tarihleri arasında özellikle de Levant ile ilişkili görünen Epi-paleolitik endüstrileri gün 1şığına çıkarmıştır ${ }^{41}$. Söz konusu yerleşimden elde edilen faunal kalıntılar öküz ve atın bol olarak avlandığını işaret etmektedir. Faunal kalıntılar açısından zıtlık gösterse de, ele geçen buluntular arasında; öğütme taşlarının varlığ 1 ile bol miktardaki yarımaylar, tıpk1 Öküzini mağarasında hemen hemen aynı tarihlere denk gelen aynı tip buluntularla büyük bir benzerlik göstermektedir. İç Anadolu Bölgesi hakkında elde edilen böylesi buluntular, geç pleistosen-erken holosen'de yaşayan avc1-toplayıcıların nitelikleri hakkındaki "gerçekçi ve gözle görülebilen" ilk ip uçlarımız olarak kabul edilebilir.

Araştırmamızı yaparken karşılaştığımız bir önemli saptama hakkında bilgi vermek yerinde olacaktır. Bilindiği üzere, yazımızda eski araştırmalar olarak nitelediğimiz Cumhuriyet Dönemi birinci ve ikinci kuşak araştırıcılarının, kazılar ya da yüzey araştırmalarıyla ele geçirdiği materyallere ulaşmamız ya çok kısıtlı olmuştur, ya da hiç ulaşamamışızdır. Dolayısıyla da bazı konularda sadece yayınlardan yola çıkarak görüşlerimizi sunmuş bulunuyoruz. Ancak Kökten'in yazmış olduğu bir makalede bakınız ne yazmaktadır, aynen aktarıyoruz: “........ Lüdumlu köyünün Perm kalkerlerinden müteşekkil bir tepenin dar bir yarıntısında bir elbaltası bulunmuştu. Bu baltasinin yapısı andezitten olup uzunluğu 13.5, genişliği 8, ve kalınlığ 4.5 santimetre çapındadır. Şelleen teknikle yapılmış olan bu elbaltasinin asl Yüksek Ziraat Enstitüsü kolleksiyonlar arasında ve çok dikkatle yapılmış olan bir benzeri de Antropoloji Enstitüsünde bulunmaktadır.........."42. Kök-

${ }^{41}$ Douglas Baird ile kişisel görüşme

42 Kökten 1947b, 438 ten aynı yayınında Haymana çevresinden ele geçen bir mezar taşı için de: “....... Haymana çevresinden toplanarak Ankara'da Ogüst mabedi deposuna kaldirılmış olduğunu ögreniyoruz ........"43 demektedir. Daha önceki kısımlarda belirtmiş olduğumuz gibi böylesi kimi buluntuların (eğer Ülkemizde ve tahrip olmamış bir şekilde kalmış ise) nerelerden bulunabileceği belli değildir. Çünkü ilgisi olmamakla birlikte bütünüyle dağılmış bulunmaktadır. Dolayısıyla eskiden ele geçmiş olan çoğu buluntu, bu şekilde eski depolara ya da çeşitli fakültelerin koleksiyonlarına konmuş ise, bunların "konu uzmanlarının" olduğu fakülte bölümlerine ya da müzelere teslim edilmesi gerekmektedir. Böylesi materyallerin nitelik ve nicelikleri ancak bu şekilde tespit edilebilir kanısındayı.

Son ve özetleyici saptamalarımız açısından konumuza dönersek, elimizdeki yontmataş materyal kanıtlara dayanarak; tipolojik ve teknolojik açıdan Etiyokuşu, Çayyolu Sondurak Çevresi, Keçiören ve Eryaman alt Paleolitik döneme tarihlenebilecek buluntular vermiştir. Öte yandan Etiyokuşu, Keçiören, Ergazi, Sindıran Yanıktarla ve Etimesgut alt Paleolitik sonu ile orta Paleolitik dönem başına; Keçiören, İlhan Çayı, Etiyokuşu, İvedik, Sındıran Yanıktarla, Ergazi, Çayyolu Sondurak çevresi ve Eryaman orta Paleolitik döneme; Etiyokuşu, Sindıran Yanıktarla Ergazi, Çayyolu Sondurak çevresi ve Eryaman ise üst Paleolitik ve/veya Epipaleolitik dönemlere tarihlenebilecek teknolojileri gün 1şı̆̆ına çıkarmıştır. Kesin fosil direktörleri olmadığı için tam olarak dönemini veremeyeceğimiz, ancak Paleolitik Çağ sonrasına tarihlenebilecek yontmataş buluntuların bazıları da Macunçay, Hüseyingazi, Keçiören ve Çayyolu Sondurak çevresinden tespit edilmiştir.

${ }^{43}$ Kökten 1947b, 447 
Eski ve yeni yontmataş buluntuların 1şığında özetlemeye çalıştığımız Ankara Paleolitik'i yeni verilere ihtiyaç duymaktadır. Az sayıda olmakla birlikte, özellikle bir takım çıkarsamalar yapmış olmamızın nedeni; ulaştığımız sonuçlara göre düşüncelerimizi tartışmaya açmaktır. Ankara ve özellikle de İç Anadolu Bölgesi'ndeki Paleolitik Çağ buluntularının artması, söz konusu tartışmalara daha bilimsel yaklaşımlar getirebilecektir kanısındayız.

\section{Teşekkür}

Dil ve Tarih-Coğrafya Fakültesi Arkeoloji Bölümü Prehistorya Anabilim Dalı Başkanı Prof.Dr.Işın Yalçınkaya'ya Anabilim Dalı koleksiyonu üzerinde çalışmam için vermiş olduğu izinlerinden dolayı çok teşekkür ediyorum. Anadolu Medeniyetleri Müzesi Müdürü Sayın Hikmet Denizli'ye ve Müze araştırıcılarından Sayın Arkeolog (MA) Zehra Fürüzan Taşkıran'a nazik yardımlarından ötürü teşekkürü bir borç bilirim. Yontmataş buluntu çizimlerindeki değerli yardımları için sevgili eşim ve meslektaşım Arkeolog Gizem Kartal'a sonsuz teşekkürler. Çalışmam sırasında yardımlarını gördüğüm Doç.Dr.Harun Taşkıran ve Arkeolog Bora Cem Sevencan'a içten teşekkürler.

\section{Yrd.Doç.Dr. Metin Kartal,}

Ankara Üniversitesi, Dil ve Tarih-Coğrafya Fakültesi, Arkeoloji Bölümü, Prehistorya Anabilim Dalı, 06100-Sihhiye / Ankara TÜRKIYYE. e-mail:kartal@humanity.ankara.edu.tr e-mail: arkeologkartal@mynet.com

\section{Figürler Listesi}

Figür 1: (1) Nacak, Çayyolu Sondurak Çevresi; (2) İki yüzeyli, Eryaman 4. Etap.
Figür 2: (1) İki yüzeyli, Keçiören; (2) İki yüzeyli, Etiyokuşu; (3) İki yüzeyli, Çayyolu Sondurak Çevresi.

Figür 3: (1) Merkezcil recurrent levallois çekirdek, Ergazi-II; (2) İki kutuplu recurrent levallois çekirdek, Keçiören; (3) Merkezcil recurrent levallois çekirdek, Etiyokuşu; (4) İki kutuplu recurrent levallois çekirdek, Eryaman 4. Etap; (5) Lineal levallois çekirdek, Ergazi-I; (6) Lineal levallois çekirdek, Keçiören; (7) Merkezcil recurrent levallois çekirdek, Ergazi-I; (8) Merkezcil recurrent levallois çekirdek, Etimesgut; (9) Merkezcil recurrent levallois çekirdek, Keçiören.

Figür 4: (1) Kenar kazıyıc1, SindıranYanıktarla; (2) Dışbükey yöneşen kenar kazıyıcı, Etiyokuşu; (3) Kırık kenar kazıyıcı (?), Keçiören; (4) Tek içbükey kenar kazıyıcı, Keçiören; (5) Tek dışbükey kenar kazıyıcı, İlhan Çayı; (6) Dışbükey yöneşen kenar kazıyıcı, Etiyokuşu; (7) İç yüzde kenar kazıyıcı, Etiyokuşu; (8) Dişlemeli alet, Etiyokuşu; (9) İki kenar kazıyıcı, Etiyokuşu.

Figür 5: (1) Levallois yonga, Etiyokuşu; (2) Ön kazıyıc1-çontuklu, İvedik; (3) Levallois yonga üzerine ön kazıyıcı, Sındıran-Yanıktarla; (4) Disk biçimli çekirdek üzerine çontuklu alet, Sındıran-Yanıktarla; (5) Kalın uç (? Charentian), Keçiören; (6) Düzeltili levallois uç, İvedik; (7) Levallois uç, Çayyolu sondurak çevresi; Levallois uç, Ergazi-II.

Figür 6: (1) Prizmatik çekirdek, Keçiören; (2) Dilgimsi yonga, Ergazi-II; (3) Dönümlü dilgi, Çayyolu sondurak çevresi; (4) Çekirdek tablası üzerine iç yüzde kenar kazıyıcı, Sindıran-Yanıktarla; (5) Orak elemanı, Hüseyingazi; (6) Orak dilgi parçası, Çayyolu sondurak çevresi; (7) Ön kazıyıcı, Çayyolu sondurak çevresi; (8) Eğik budanmış dilgi, Macunçay; (9) Dilgi üzerine kenar kazıyıcı, Etiyokuşu. 


\section{KAYNAKÇA}

Harmankaya-Tanındı 1996

İnan 1938

Kansu 1940

Kansu-Ozansoy 1952

Kartal 2003

Kozlowski-Kaczanowska 2004

Kökten 1947a

Kökten 1947b

Kökten 1952

Kökten 1953

Movious 1944

Movious 1948

Otte ve diğ. 1999

Özçelik 2003

Özdoğan 1999

Taşkıran 1990
Savaş Harmankaya ve Oğuz Tanındı, Türkiye Arkeolojik Yerleşmeleri (Paleolitik /Epipaleolitik), Ege Yayınları, İstanbul (1996).

Afet İnan, "Uğurlar Olsun-Açık Eti Mağbedi'nde”, Ülkü Halkevleri ve Halkodaları Dergisi”, Cilt XI, Say1 64 (Haziran), (1938): 293-301.

Şevket Aziz Kansu, Etiyokuşu Hafriyatı Raporu (1937), Türk Tarih Kurumu Yayınları, Ankara (1940).

Şevket Aziz Kansu ve Fikret Ozansoy, “Ankara Civarında Paleolitik Yeni Buluntular”, IV. Türk Tarih Kongresi (1952): 381-390.

Metin Kartal, “Anadolu'nun Epi-paleolitik Dönem Buluntu Toplulukları: Sorunlar, Öneriler, Değerlendirmeler ve Çeşitli Yaklaşımlar-Anatolian Epipaleolithic Period Assemblages: Problems, Suggestions, Evaluations and Various Approaches", Anadolu/Anatolia, 24 (2003): 35-61.

Janusz Kozlowski ve Malgorzata Kaczanowska, "Gravettian/Epigravettian Sequences in the Balkans and Anatolia", Mediterranean Archaeology and Archaeometry, Vol. 4, No 1 (2004):5-18.

İsmail Kılıç Kökten, "Bazı Prehistorik İstasyonlar Hakkında Yeni Gözlemler”, Ankara Üniversitesi Dil ve Tarih Coğrafya Fakültesi Dergisi, Cilt V, Say1 2 (1947): 223-236.

İsmail Kılıç Kökten, "1945 Yılında Türk Tarih Kurumu Adına Yapılan Tarihöncesi Araştırmaları”, Belleten, Cilt XI, Sayı 43 (1947): 431-472.

İsmail Kılıç Kökten, “Anadolu'da Prehistorik Yerleşme Yerlerinin Dağılışı Üzerine Bir Araştırma", Ankara Üniversitesi Dil ve Tarih Coğrafya Fakültesi Dergisi, Cilt X, Say1 3-4 (1952): 167-207.

İsmail Kılıç Kökten, "1952 Yılında Yaptığım Tarihöncesi Araştırmaları Hakkında", Dil ve Tarih-Coğrafya Fakültesi Dergisi, Cilt XI, Sayı 2-4, (1953): 177-209.

Hallam Movious, "Early Man and Pleistocene Stratigraphy in Southern and Eastern Asia", Papers of the Peabody Museum of American Archaeology and Ethnology, 19 (1944): 1-125.

Hallam Movious, "The Lower Paleolithic Cultures of Southern and Eastern Asia", Transactions of the American Philosophical Society, 38 (1948): 329420 .

Marcel Otte, Işın Yalçınkaya, Ofer Bar-Yosef, Janusz Kozlowski, Jean-Marc Léotard, Harun Taşkıran, Pierre Noiret ve Metin Kartal, "The Anatolian Palaeolithic: Data and Reflections", The Palaeolithic Archaeology of Greece and Adjacent Areas (1999): 73-85.

Kadriye Özçelik, "Karain Mağarası B Gözü’nde Üst Paleolitik Sorunu”, Anadolu/Anatolia, 25, (2003): 83-95.

Mehmet Özdoğan, "Northwestern Turkey: Neolithic Cultures in Between the Balkans and Anatolia", Neolitic in Turkey (1999): 203-224, Pl. 171-194.

Harun Taşkıran, Biçimsel Tipoloji Açısından Anadolu İki Yüzeyli Aletleri, Ankara Üniversitesi Sosyal Bilimler Enstitüsü Yayınlanmamış Yüksek Lisans Tezi, Ankara (1990). 
Tașkıran 1998

Taşkıran 2002

Taşkıran-Kartal 2004

Yalçınkaya 1989
Harun Taşkıran, "The Distribution of Bifaces in Anatolia", Préhistoire D'Anatolie Genèse de Deux Mondes-Anatolian Prehistory at the Crossroads of Two Worlds, Vol.II, ERAUL 85, (1998): 569-577.

Harun Taşkıran, “2000 Yılı Karkamış Baraj Gölü Alanı Paleolitik Çağ Yüzey Araştırması"-"The Palaeolithic Survey in the Carchemish Dam Reservoir Region: 2000 Season, Ilısu ve Karkamış Baraj Gölleri Altında Kalacak Arkeolojik ve Kültür Varlıklarını Kurtarma Projesi 2000 Yılı ÇalışmalarıSalvage Project of the Archaeological Heritage of the Ilisu and Carchemish Dam Reservoirs Activities in 2000, (eds.) Numan Tuna-Jale Velibeyoğlu, ODTÜ Taçdam Yayınları (2002): 383-429.

Harun Taşkıran ve Metin Kartal, "2001 Y1lı Ilısu Baraj Gölü Alanı Paleolitik Dönem Yüzey Araştırması”, Ilısu ve Karkamış Baraj Gölleri Altında Kalacak Arkeolojik ve Kültür Varlıkların Kurtarma Projesi 2001 Yılı ÇalışmalarıSalvage Project of the Archaeological Heritage of the Illsu and Carchemish Dam Reservoirs Activities in 2001, (eds.) Numan Tuna, Jean Greenhalgh, Jale Velibeyoğlu, ODTÜ Taçdam Yayınları (2004): 695-737.

Işın Yalçınkaya, Alt ve Orta Paleolitik Yontmataş Endüstrileri Biçimsel Tipolojisi ve Karain Mağarası, Türk Tarih Kurumu Basımevi, Ankara (1989). 

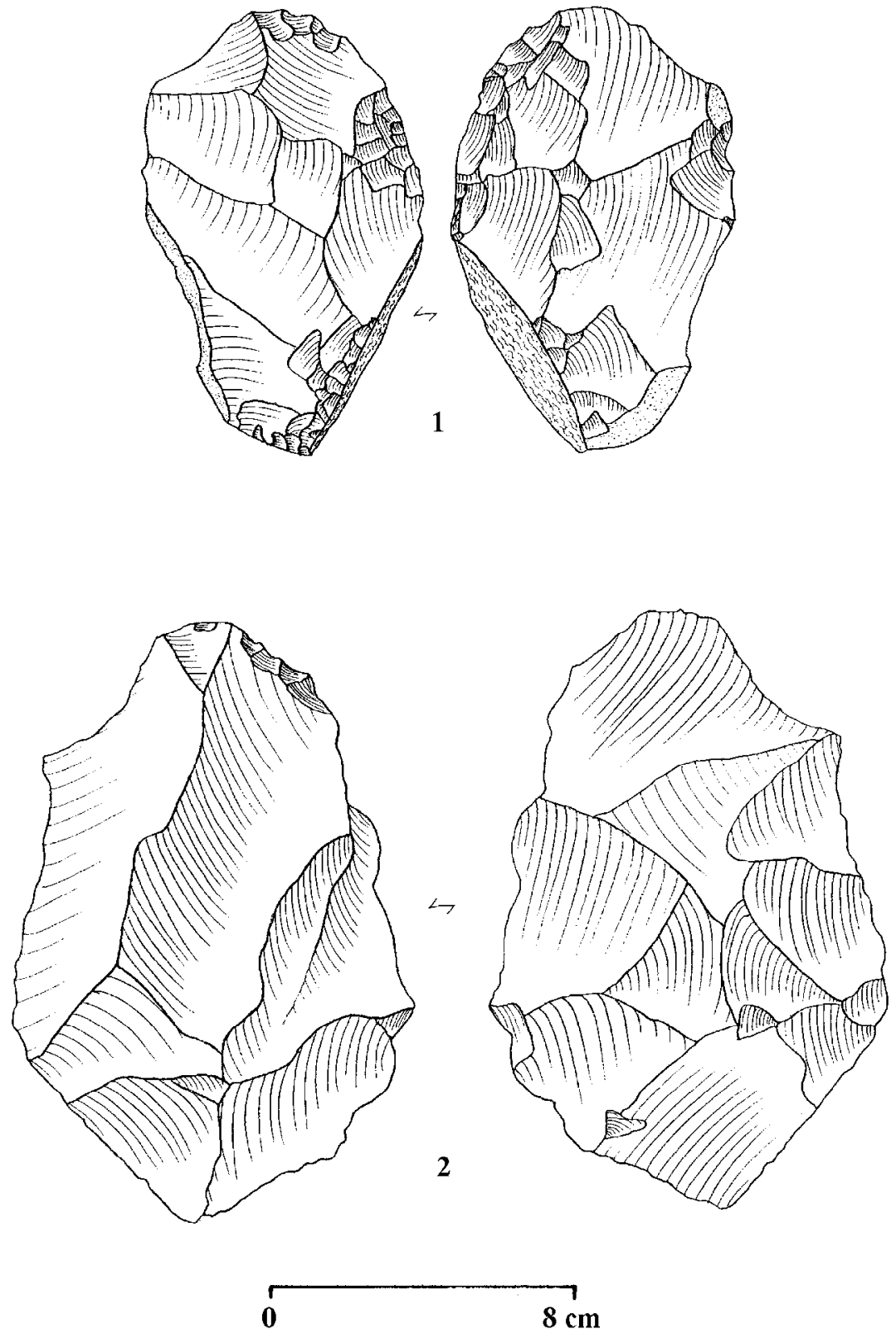

Figür 1 
Yontmataş Buluntu Toplulukları Işı̆̆ında Ankara: Neyi Biliyoruz? Neyi Bilmiyoruz?
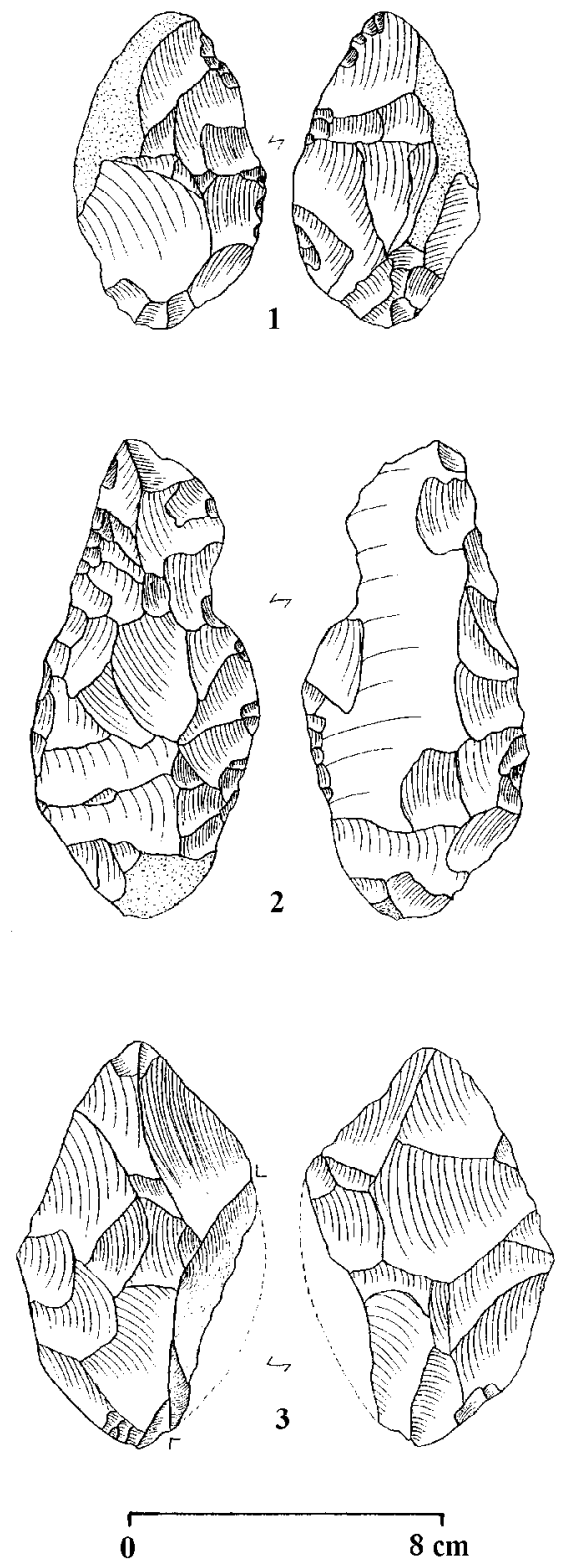

Figür 2 

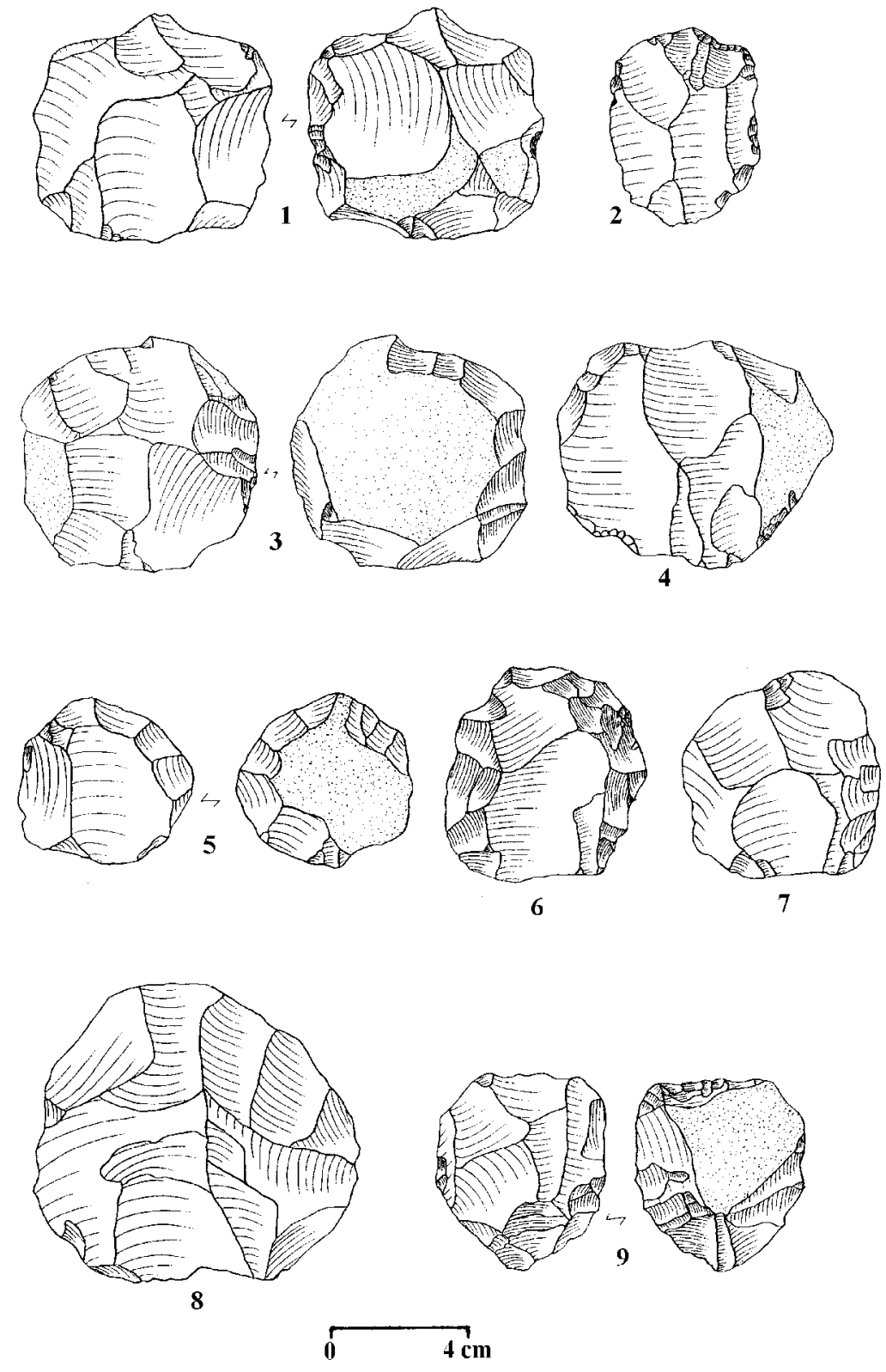

Figür 3 
Yontmataş Buluntu Toplulukları Işı̆̆ında Ankara: Neyi Biliyoruz? Neyi Bilmiyoruz?
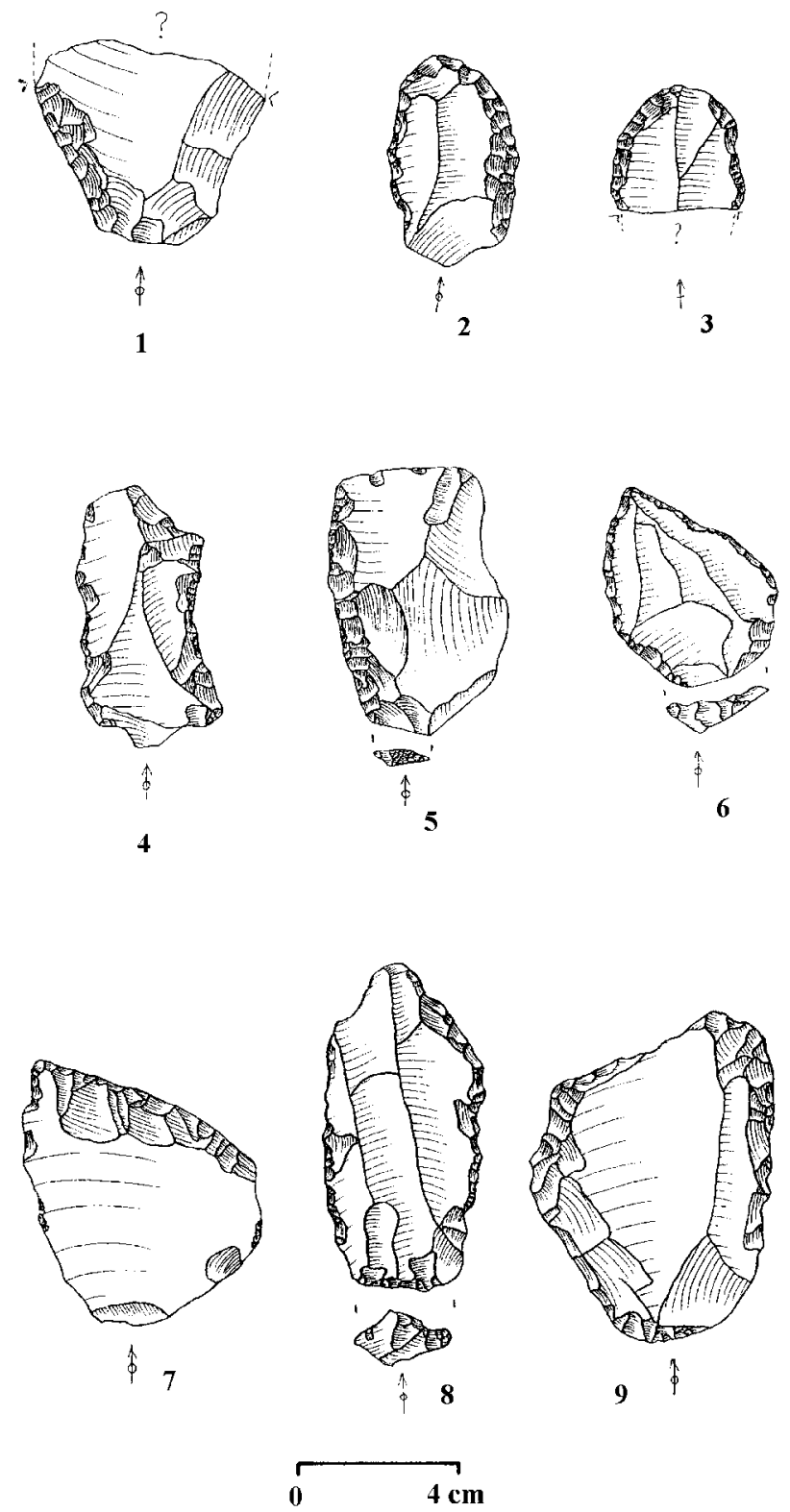

Figür 4 


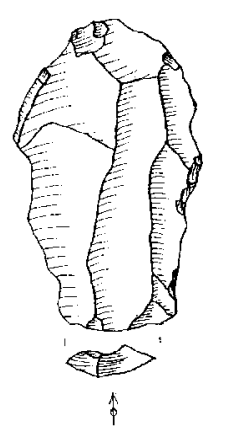

1
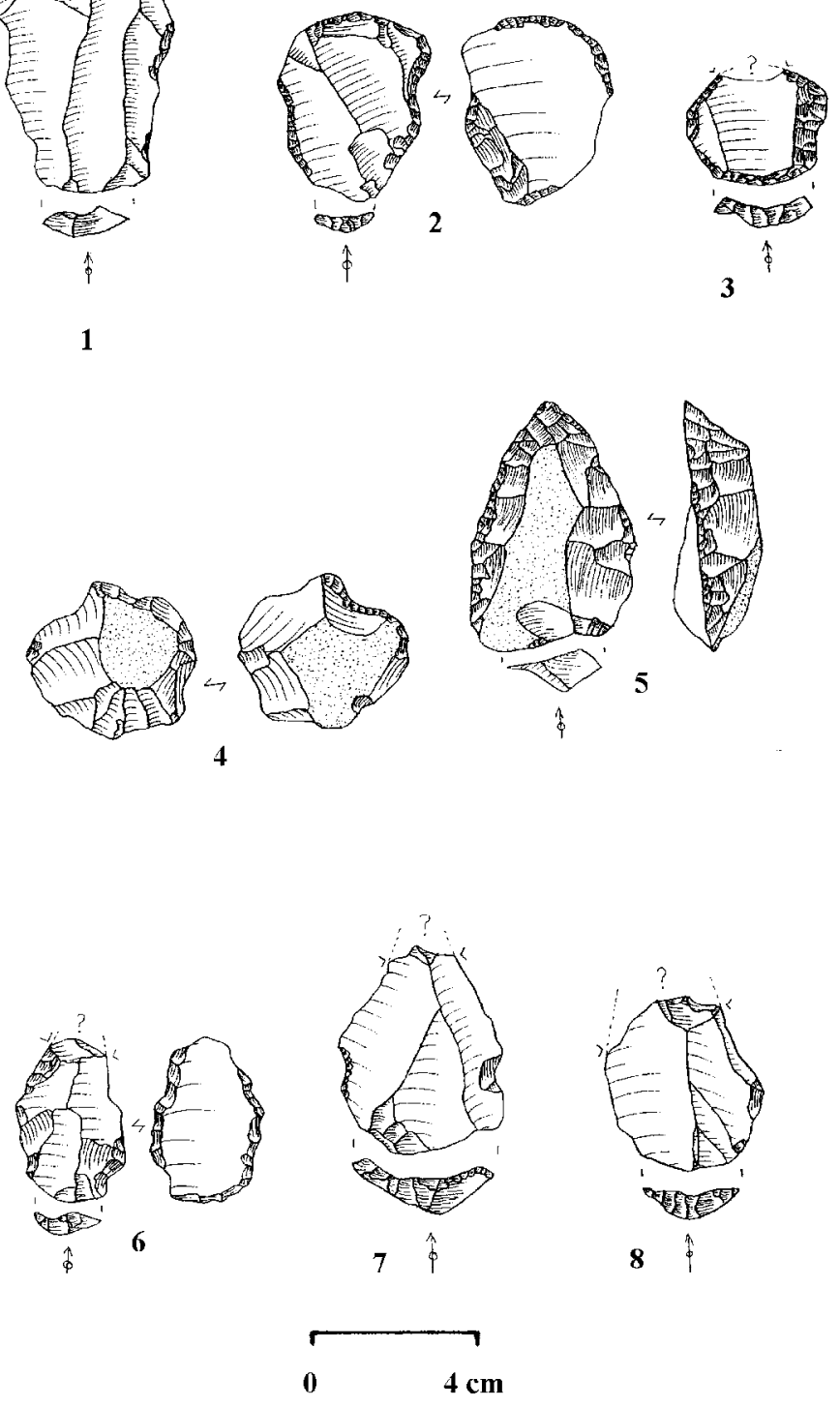

Figür 5 
Yontmataş Buluntu Toplulukları Işı̆̆ında Ankara: Neyi Biliyoruz? Neyi Bilmiyoruz?

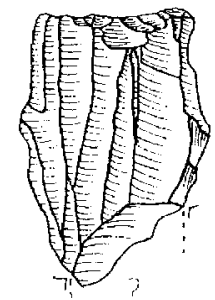

1

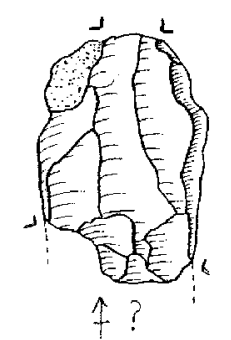

2

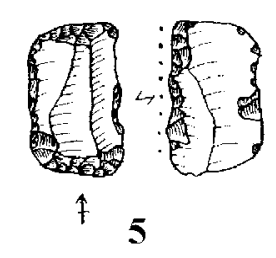

4

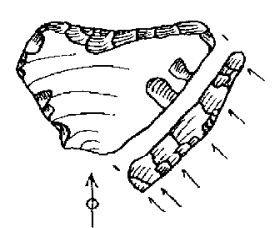

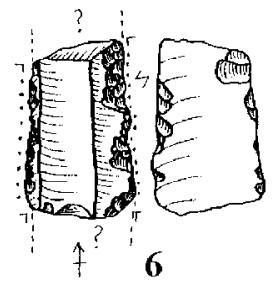
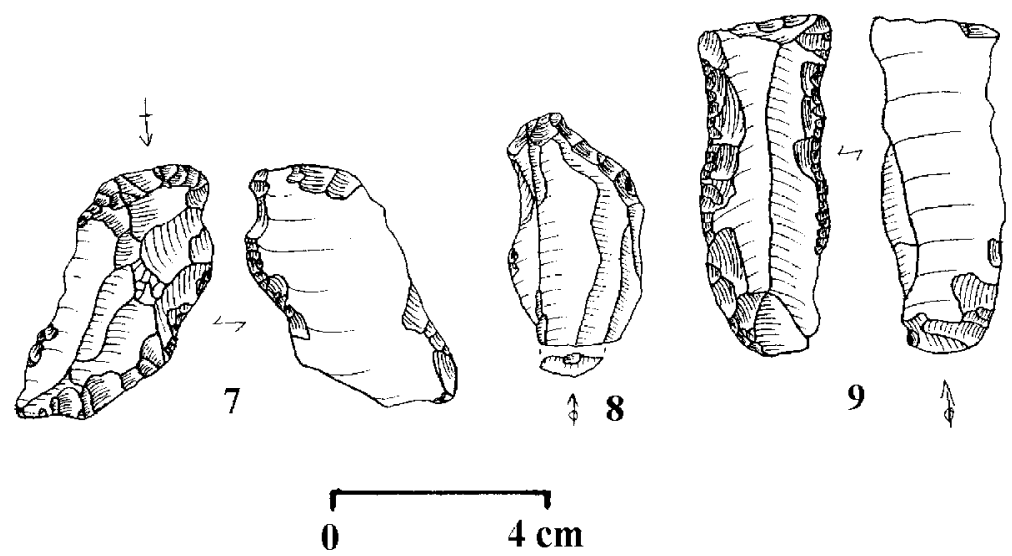

Figür 6 